\title{
The Role of Production Factors on Tilapia Farming Business in Toba Samosir District
}

\author{
Julia Marisa $^{1^{*}}$ and Sukma Aditya Sitepu ${ }^{2}$ \\ ${ }^{1)}$ Department of Agroecotechnology, Faculty of Sains and Technology, Universitas Pembangunan Panca \\ Budi, Medan, Indonesia \\ ${ }^{2)}$ Department of Animal Husbandry, Faculty of Sains and Technology, Universitas Pembangunan Panca \\ Budi, Medan, Indonesia
}

\begin{abstract}
Tilapia farming system is a business system consisting of components that are interrelated to the farming of tilapia. Tilapia farmers in Toba Samosir Regency do not consider spending on factors of their business production so that the capital spent becomes large and influences the income of farmers. The purpose of community service implementation is to conduct an introduction to the factor analysis of tilapia business production so that farmers can do business efficiency and increase their income. The result of community service is that farmers start to analyze which factors of production need to be increased to increase income and factors that need to be reduced to reduce expenditure so that tilapia fish business income increases.
\end{abstract}

Keywords: Production Factors, Revenue, Tilapia

\begin{abstract}
Abstrak. Sistem usahatani nila adalah sistem bisnis yang terdiri dari komponen-komponen yang saling terkait dengan budidaya nila. Petani nila di Kabupaten Toba Samosir tidak mempertimbangkan pengeluaran pada faktor-faktor produksi bisnis mereka sehingga modal yang dihabiskan menjadi besar dan mempengaruhi pendapatan petani. Tujuan dari implementasi pengabdian pada masyarakat adalah untuk melakukan pengantar analisis faktor produksi bisnis nila sehingga petani dapat melakukan efisiensi bisnis dan meningkatkan pendapatan mereka. Hasil dari pengabdian masyarakat adalah bahwa petani mulai menganalisis faktor-faktor produksi mana yang perlu ditingkatkan untuk meningkatkan pendapatan dan faktor-faktor yang perlu dikurangi untuk mengurangi pengeluaran sehingga pendapatan usaha ikan nila meningkat.
\end{abstract}

Kata Kunci: Faktor Produksi, Keuntungan, Ikan Nila

Received 11 December 2018 | Revised 25 Februaryy 2019| Accepted 4 March 2019

\footnotetext{
*Corresponding author at: J1. Gatot Subroto KM 4,5 Medan 20122, North Sumatera, Indonesia

E-mail address: juliamarisa2@gmail.com
} 


\section{Introduction}

Toba Samosir is one of the districts in North Sumatra which is surrounded by Lake Toba and its capital city is Balige. It has a1,1302 $\mathrm{km} 2$ surface area and a maximum depth greater than $500 \mathrm{~m}$, and as a largest lake in Indonesia, and also the larest volcanic-crater lake in the world [1]. Toba Samosir Regency is very potential for the development of fisheries, both capture, and cultivation, in order to improve the economy of the region. The total production of fish from cage aquacultute in Toba Lake in 2010 are 47,478 tons [2]. This causes the unemployment rate in Toba Samosir to decrease and economic growth and development will grow rapidly. One of the fisheries businesses conducted by the Toba Samosir community is the tilapia business. Tilapia is a valuable food fish and most wide-spread species for production of aquaculture in the world [3].

The phenomenon is that the farmers in Toba Samosir District do their business without considering the factors of production that affect their tilapia farming business. This causes the capital used in doing business to be large so that the income of tilapia farmers becomes low. By analyzing the factors of production of tilapia businesses so that farmers can do business efficiency by considering which factors need to be reduced and which parts should be increased so that they are expected to later increase farmers' income [4].

\section{Method}

The method of service to solve the problem of tilapia farmers is to provide:

- Lectures and Discussion. lecture material was given to participants. After finishing the lecture, continued with discussion and practice directly in the field. Lecture materials are:

- The potential for tilapia farming in Indonesia,

- Calculation of income and economic feasibility of tilapia fish business,

- Analysis of factors that influence tilapia business.

- Practice.

Perform analysis of business production factors tilapia in Toba Samosir. Tilapia breeders in Toba Samosir District after receiving lectures and socialization are expected to conduct an analysis of the factors of production so that the business is effective and efficient to increase income. 


\subsection{Procedure}

Work procedures to support the realization of the solutions offered, then first make an initial observation in the field approach through interviews and find the phenomenon problems. After observation and socialization, the problem was examined and found a solution to be offered, then prioritized the implementation phases and then did the service by providing counseling and practice. The last is to evaluate the results by observing again the progress of the tilapia business.

\subsection{Evaluation of Service Implementation}

Evaluation of the implementation of the service and sustainability program after completion of the field service activities, where evaluation of the results will be carried out by observing the progress of the community tilapia business by the service team.

\section{Result and Discussion}

From the results of the program that has been carried out in the community service in Toba Samosir District, after it was observed again it was known that there had been some changes to a better direction. according to the explanation of the results. The results of community service are as follows:

1. Based on the monitoring results back to the analysis of production factors farming tilapia, seen farmers start to think and calculate the cost incurred on each factor of production in more detail include capital, labor, feed, the scale of operations and the use of medicine during the conduct of the business of cattle tilapia to find out which factors need to be improved and reduced to obtain maximum income,

2. Farmers claim that now they have more attention to the analysis of production factors tilapia farming,

3. Farmers claim to have understood the importance of analyzing the factors of production of tilapia livestock business so that they learn to streamline their operational costs in doing their business in order to increase business income,

4. Farmers gain understanding and knowledge about how to analyze the factors of production of tilapia fish farming business.

Before community service is carried out, farmers do not consider the factors of production of tilapia farming business. After community service, farmers start thinking and calculating the costs incurred in each factor of production in detail including capital, labor, feed, business scale and use of medicines during their business. Tilapia farmers 
realize the importance of doing the analysis of production factors tilapia farming so that they can determine how much revenue earned and plan effective use of operational costs to increase the income of farmers.

To improve knowledge and understanding of the analysis factors production of tilapia farms in Toba Samosir District, further extension is needed so that farmers are more aware of the importance conducting factors analysis of production factors to see the effectiveness production costs and business feasibility [5].

With an understanding of the analysis of the factors of production of tilapia livestock business that is good, the breeders can manage their income well in accordance with the efficiency of the use of production costs [6]. In addition to the factor analysis, training for tilapia cultivation and marketing training is needed so that production increases and farmers can obtain a good selling price so as to increase the income and welfare of farmers [4].

\section{Conclusion}

After conducting community service in Toba Samosir Regency, it was found that there were some real changes in the factors affecting the production of tilapia fish farming. Farmers have gained understanding and knowledge about how to analyze factors of production effectively and efficiently so that it can support the income of tilapia farmers. It is recommended that extension counseling be carried out related to other things needed by tilapia farmers in Toba Samosir Regency to increase knowledge so that the tilapia livestock business will improve.

\section{References}

[1] Chesner, C.A. 2011. The Toba caldera complex. Quaternary International. In press. Available at: http://www.geo.mtu.edu/ raman/papers2/Toba\%20QI.pdf.

[2] Anonymous, 2011. Statistik Perikanan Budidaya Provinsi Sumatera Utara Tahun 2010 (Aquaculture statistic of North Sumatera Province 2010). Laporan Tahunan. Dinas Kelautan dan Perikanan Provinsi Sumatera Utara. 148 hal. (In Indonesia).

[3] Fitzsimmons, K., R. Martinez-Garcia and Pablo Gonzalez-Alanis (2011) Why Tilapia is becoming the most Important Food Fish on the Planet. In: L. Liping and K. Fitzsimmons (Eds.) Proceedings ofthe 9th International Symposium on Tilapia in Aquaculture. Shanghai Ocean University, Shanghai, China, April 22-25, 2011.

[4] Soekartawi. 2002. Prinsip Dasar Ekonomi Pertanian Teori dan Aplikasi. Jakarta: PT. Raja Grafindo. 
[5] Prawirokusumo, Y. B., 1991. Ilmu Usahatani. BPFE, Yogyakarta.

[6] Aritonang, D. 1993. Perencanaan dan Pengelolaan Usaha. Penebar Swadaya, Jakarta. 